\title{
Report of The Research and Survey Committee of New Materials for Lighting
}

\author{
Reporter; Noboru ICHINOSE* \\ * Waseda University
}

\section{Introduction}

It is well known that materials play very important role in development of light sources. In previous paper', ceramic materials as a light source material were reported. Here, we report new materials including ceramic materials for high efficiency lamp and lamp system. New materials are devided into four groups, i.e. organic materials, metals, inorganic materials and semiconducting device materials. Among them, the following topics are reported;

(1) functional polymers, organic nonlinear optical materials and super engineering plastics for organic materials, (2) amorphous metal alloys and amorphous silicon for metals. (3) optical disk materials, new glasses, electro-optical crystals, optical fibers and translucent YAG (yttrium aluminum garnet) ceramics for inorganic materials, (4) visible lasers and CCD imager materials for semiconducting device materials.

The Research and Survey Committee of New Materials for Lighting was established in August, 1988 and since then the committee was held 14 times until February, 1991, wherein the current and future trend of new materials for lighting was studies energetically. This report is summary thereof.

\begin{tabular}{|c|c|c|}
\hline \multicolumn{3}{|c|}{ (Member of the Committee) } \\
\hline Chairman: & N. Ichinose & (Waseda University) \\
\hline \multirow[t]{2}{*}{ Secretary: } & K. Narita & (Toshiba Co., Ltd.) \\
\hline & K. Nagata & $\begin{array}{l}\text { (National Defence Acad- } \\
\text { emy) }\end{array}$ \\
\hline \multirow[t]{6}{*}{ Member: } & H. Takahashi & $\begin{array}{l}\text { (Matsushita Electric Works, } \\
\text { Ltd.) }\end{array}$ \\
\hline & N. Igarashi & (Toshiba Ceramic Co., Ltd.) \\
\hline & T. Ohmori & (Toshiba Glass Co., Ltd.) \\
\hline & K. Watanabe & $\begin{array}{l}\text { (Mitsubishi Denki Co., } \\
\text { Ltd.) }\end{array}$ \\
\hline & H. Matsuno & $\begin{array}{l}\text { (Hitachi Seisakusho Co., } \\
\text { Ltd.) }\end{array}$ \\
\hline & M. Meisei & $\begin{array}{l}\text { (Matsushita Electronics } \\
\text { Co., Ltd.) }\end{array}$ \\
\hline
\end{tabular}

$\begin{array}{ll}\begin{array}{l}\text { Y. Suzuki } \\ \text { M. Mashita }\end{array} & \begin{array}{l}\text { (Asahi Glass Co., Ltd.) } \\ \text { S. Miyata }\end{array} \\ \begin{array}{l}\text { (Tokyo University of Agri- } \\ \text { culture and Technology) } \\ \text { (Railway Technical Re- }\end{array} \\ \text { F. Ohishi } & \begin{array}{l}\text { search Institute, J.N.R.) } \\ \text { (National Research Insti- }\end{array} \\ \text { M. Honma } & \begin{array}{l}\text { tute for Metals) } \\ \text { (Nikken Kensetsu Co., }\end{array} \\ & \text { Ltd.) }\end{array}$

\section{Progress Report}

The committee was held 14 times and in the Committee the proposed current problems were discussed mainly in reference to member's opinion from the standpoint of his specialized field and a hearing from relating specialists. Also, a lecture meeting and a symposium were held.

\subsection{Lecture meeting and Symposium}

An educational activity for the members of the Illu. Eng. Inst. of Japan was sponsored by the Committee, in which one lecture meeting and one symposium were held.

\section{2-1-1 Lecture meeting (May 13, 1992)}

It was held mainly concerning new materials jointly with the Subcommittee of Survey of Optically Relating Materials and Device, Study Group for Conducting Ceramics in the Electrochemical Society of Japan, and Sensor Research Society for Next Generation.
(1) General N. Ichinose (Waseda University)
(2) Transparent materials (Ceramics and Crystals) K. Nagata (National Defence Academy)
(3) Opto-electronic glass Y. Suzuki (Asahi Glass Co., Ltd.)
(4) Amorphous silicon K. Kuwano (Sanyo Electric Co., Ltd.)
(5) Optical semiconductors M. Okajima (Toshiba Co., Ltd.) 


\subsubsection{Symposium (Sept. 11, 1991)}

A symposium titled as "Research trend of new materials for lighting" was held in 1992, as Joint Meeting of Institutes Relating to Electrics and Informations.

(1) General "Current trend of new materials for lighting"

N. Ichinose (Waseda University)

(2) Translucent ceramics

K. Nagata (National Defence Academy)

(3) Fluorescent materials

S. Kamiya (Matsushita Electronics Co., Ltd.)

(4) Infrared reflecting films
Y. Uge
(Toshiba Co., Ltd.)

(5) Amorphous silicon

K. Kuwano (Sanyo Electrics Co., Ltd.)

(6) Low loss optical fibers

S. Takahashi (N.T.T. Public Corp.)

\section{Present Status of New Materials}

New materials such as organic materials, metals, inorganic materials and semiconducting device materials are featured and suveyed in relation to illumination, especially light sources.

\subsection{Organic materials}

\subsubsection{Functional polymers}

The polymetric materials are innovative materials in- cluding rubbers, plastics, liquid macromolecules and adhesives. They are the industrial materials of macromolecules, in which a large number of structural units are connected in chain. Since the first oil crisis in 1973, new functions have been studied for polymetric materials. Functional polymers are very important for optical applications as shown in Fig. 1.

Among them, there are many functional organic materials such as conducting organic polymer, organic superconductors, optically conducting materials, display device materials, piezo- and pyroelectric materials, magnetic materials, photoresist materials, recording materials, optical transmittance materials and lens materials in relation to optical applications.

\subsubsection{Nonlinear optical materials}

Nonlinear optical (NLO) thin films are key materials for photonic systems such as optical communication, optical computers and optical neural networks. For example, NLO films with large-order electrical susceptibility $\chi^{(3)}$ can be used to construct a learning synaptic connection due to their optical bistabilities. They will also lead to photonic switching with processing speeds of nearly $1 \mathrm{~Tb} / \mathrm{s}$ because they control the light signal by light. That is, we can eliminate the conversion and reconversion between optical and electrical signals. The realization of such NLO thin films will therfore lead to substantial changes in communications systems and information processing systems. Organic NLO films have great potential for these applications because of their fast response time. However, these films must be improved for

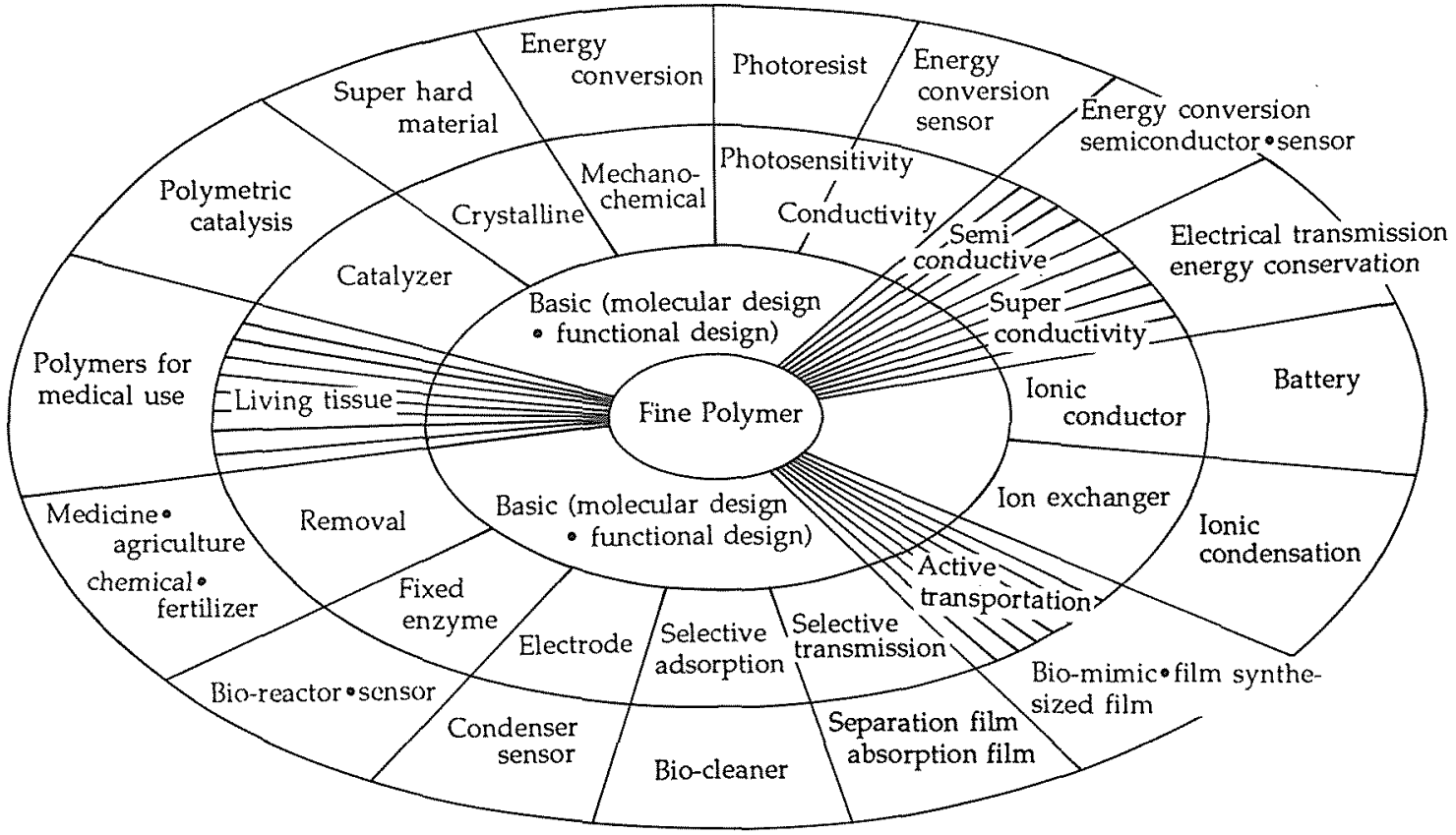

Fig. 1 Application fields of high performance functional polymers 
optical transmittance and stabilities compared with inorganic SHG (Second Harmonic Generation) materials such as $\mathrm{LiNbO}_{3}$ and $\mathrm{KTP}\left(\mathrm{KTiOPO}_{4}\right)$.

\subsubsection{Super engineering plastics}

High performance engineering plastics (named "Super Engineering Plastics"; S.E.P. in Japan) have been considered as practical materials of great promise for not only thermal use but also mechanical use. S.E.P. is not defined academically, but it includes materials as shown in Table 1. Concerned with these materials, data on their torsional performance and endurance are practically scanty. The following five kinds of S.E.P.; PPS (Poly-phenylene sulfide), PES (Polyether Sulfone), PEEK (Polyetherether Ketone), Polyamides and Polyacetal were studied for thermal and mechanical properties.

Table 1 Commercially available S.E.P.

\begin{tabular}{|c|c|c|}
\hline Material & Trade Name & Composition \\
\hline PPS & $\begin{array}{l}\text { Susteer } \\
\text { Fortron } \\
\text { Ryton }\end{array}$ & \\
\hline PES & Victrex & $(0-$ so -0 \\
\hline PEEK & Victrex & \\
\hline Polyamide & Nylon 4.6 & $\mathrm{M}-\left(\mathrm{HN}-\left(\mathrm{CH}_{2}\right)_{4}-\mathrm{NH}-\mathrm{CO}-\left(\mathrm{CH}_{2}\right)_{4}-\mathrm{CO}\right)_{n}-\mathrm{OH}$ \\
\hline Polyacetal & $\begin{array}{l}\text { Xydar } \\
\text { Vectra } \\
\text { U-polymer }\end{array}$ & \\
\hline
\end{tabular}

\subsection{Metals}

\subsubsection{Amorphous magnetic alloys}

Nowadays, amorphous magnetic alloys have been studied and used for many applications. Fe-based soft magnetic alloys are only used in the low frequency range because of their poor soft magnetic properties in the high frequency range compared to those of Co-based amorphous alloys. Here, the magnetic properties of Fe-Si-B-M (M: additives) alloys prepared by annealing amorphous alloys made by the single roller method over their crystallization temperature have been investigated for development of Fe-based soft magnetic alloys. Excellent soft magnetic properties (Table 2) were obtained by adding the two elements $\mathrm{Cu}$ and $\mathrm{Nb}$ to $\mathrm{Fe}-\mathrm{Si}-\mathrm{B}$ alloys. It was found that these new alloys, called as "FINMET", have an ultrafine grain structure composed of bcc Fe solid solution. They are suitable for many kinds of magnetic components such at saturable reactors, choke coils, and transformers, because they have superior soft magnetic properties and a high saturation flux density, and because different types of B-H hysteresis loops are obtained by magnetic field annealing.

\subsubsection{Amorphous silicon}

Compound semiconductors such as GaAs and CdTe are being used in solar cells, but certainly silicon-based materials are used predominantly based on safety and the amount of resources available. In fact, over $95 \%$ of solar cells in production are silicon based. Among them, there are three kinds of cells such as crystal-Si (c-Si), polycrystalline-Si (poly-Si) and amorphous-Si (a-Si) solar cells, depending on the method of fabrication. The production method for a-Si solar cells is different greatly from that of two other cells because a gas such as $\mathrm{SiH}_{4}$ is decomposed using glow discharge and then deposited 
Table 2 Typical magnetic properties of FINEMET and amorphous alloys. F: FINEMET.

A: Amorphous alloy. Alloy 1: $\mathrm{Fe}_{73.5} \mathrm{Cu}_{1} \mathrm{Nb}_{3} \mathrm{Si}_{13.5} \mathrm{~B}_{9}$ (at. \%).

Alloy 2: $\mathrm{Fe}_{73.5} \mathrm{Cu}_{4} \mathrm{Nb}_{3} \mathrm{Si}_{16.5} \mathrm{~B}_{6}$ (at. \%). Core loss $100 \mathrm{kHz}, 0.2 \mathrm{~T}$

\begin{tabular}{|c|c|c|c|c|c|c|c|c|c|}
\hline & Alloy & $\begin{array}{c}t \\
(\mu \mathrm{m})\end{array}$ & $\begin{array}{l}\mathrm{B}_{\mathrm{s}} \\
(\mathrm{T})\end{array}$ & $\begin{array}{c}\mathrm{B}_{\mathrm{r}} / \mathrm{B}_{\mathrm{s}} \\
(\%)\end{array}$ & $\begin{array}{c}H_{c} \\
(\mathrm{~A} / \mathrm{m})\end{array}$ & $\begin{array}{c}\mu_{e} \\
(1 \mathrm{kHz})\end{array}$ & $\begin{array}{c}\text { Core loss } \\
\left(\mathrm{kW} / \mathrm{m}^{3}\right)\end{array}$ & $\begin{array}{c}\lambda_{s} \\
\left(\times 10^{-6}\right)\end{array}$ & $\begin{array}{c}\text { Curie temp. } \\
\text { (K) }\end{array}$ \\
\hline \multirow[t]{5}{*}{$\mathrm{F}$} & Alloy 1 & 18 & 1.24 & 54 & 0.53 & 100000 & 280 & +2.1 & 843 \\
\hline & Alloy 2 & 18 & 1.18 & 58 & 1.1 & 75000 & 280 & $\sim 0$ & 833 \\
\hline & $\mathrm{FT}-1 \mathrm{H}$ & 20 & 1.35 & 90 & 0.8 & 5000 & 950 & +2.3 & 843 \\
\hline & FT-1M & 20 & 1.35 & 60 & 1.3 & 70000 & 350 & +2.3 & 843 \\
\hline & FT-1L & 20 & 1.35 & 7 & 1.6 & 22000 & 310 & +2.3 & 843 \\
\hline \multirow[t]{2}{*}{$A$} & Fe-Si-B-M & 20 & 1.41 & 16 & 6.9 & 6000 & 460 & +20 & 631 \\
\hline & Co-Fe-Si-B-M & 18 & 0.53 & 50 & 0.32 & 80000 & 300 & $\sim 0$ & 453 \\
\hline
\end{tabular}

on a substrate such as glass. So, a-Si solar cells have the following advantages:

(1) Production processes for a-Si solar cells are simple.

(2) The energy required for production is low with processes demanding less than $300^{\circ} \mathrm{C}$.

(3) The use of gas reaction facilitates larger sizes.

These and other characteristics make a-Si solar cells ideal low-cost. In 1988, production share of a-Si solar cells in Japan was $75 \%$.

\subsection{Inorganic materials}

\subsubsection{Optical disk materials}

Optical recording, which involves using laser beam matching in a thin film medium, allows extremely high density information storage. The development of a suitable recording medium is currently the subject of a grat deal of interest. It is well known that there are three types of systems such as read only memory (ROM), direct read after write memory (DRAM) and erasable DRAM (EDRAM).

For these systems, many different optical recording media have been investigated. Among these media, usual polycrystalline Te films have many attractive recording characteristics, but show rapid degradation in a high humidity environment. It is necessary for optical recording media to satisfy the high sensitivity and long-term stability at least. In order to increase the Te stability, alloying Te with Se, $\mathrm{Sb}$ and As has been studied. Alloying also makes films amorphous. Other approaches to improving the stability are plastic overcoating and air sandwich structure. These methods have a tendency to reduce sensitivity, or structural simplicity. A suitable recording media is now strongly required. Here, a new optical recording media $\mathrm{Te}-\mathrm{C}$ has been reported. Merits of this media are high sensitivity, long-term stability, lowcost due to simple structure media and nontoxicity compared to Te films.

\subsubsection{Optoelectronic crystals}

Optoelectronics are new fields which combine optics and electronics. Optoelectronic materials are defined as materials which are provided with both features outstandingly. In optoelectronic materials, usually single crystals are used. This is because they have features such as no scattering, fixed crystal orientation and uniformity. Representative optoelectronic materials are $\mathrm{LiNbO}_{3}$, $\mathrm{LiTaO}_{3}, \mathrm{Ba}_{2} \mathrm{NaNb}_{5} \mathrm{O}_{12}, \mathrm{KNbO}_{3}, \mathrm{PbMoO}_{4}$ and $\mathrm{TeO}_{2}$.

\subsubsection{Optical fibers}

The development of low loss optical fibers has brought about a revolution in the field of telecommunication system because of their promising applications in long repeaterless links and high-capacity transmission system. Transmission loss and dispersion are the most important characteristics of the fiber for telecommunications use.

The attenuation in silica fibers has been reduced to the theoretical lower limit, $0.2 \mathrm{~dB} / \mathrm{km}$ at a infrared wavelength of $1.55 \mu \mathrm{m}$. At the present stage, high quality silica fibers are adopted to long repeater span telecommunication systems in practical use.

\subsubsection{Translucent YAG ceramics}

Since an invention of translucent alumina $\left(\mathrm{Al}_{2} \mathrm{O}_{3}\right)$, a number of light transmissive ceramics including $\mathrm{MgO}$, $\mathrm{Y}_{2} \mathrm{O}_{3}$, and $\mathrm{ZrO}_{2}$ has appeared successively. Recently, a 
piezoelectric ceramic called as PLZT composed of $\mathrm{PbTiO}_{3}-$ $\mathrm{PbZrO}_{3}-\mathrm{La}_{2} \mathrm{O}_{3}$ became the topics in the electo-optic materials. This ceramic shows an excellent electro-optic effect so that its application as a new optical material for information processing, instead of single crystal, is expected.

Among these translucent ceramics, $\mathrm{Y}_{3} \mathrm{Fe}_{5} \mathrm{O}_{12}(\mathrm{YAG})$ is a promissing new material for laser host material. Here, new processing for obtaining high transmittance YAG has been reported.

\subsubsection{New glasses}

New glasses in Japan were defined as follows; (1) glasses, (2) amorphous substances, (3) crystalline substances made from glasses and amorphous substances, (4) composite materials based on glasses, amorphous substances or crystals obtained from them.

Above mentioned, new glasses are completely different from conventional glasses such as container and plate glasses, and have been developed in these twenty years. For example, fiber glasses for optical communication laser glasses for nuclear fusion and bioactive glass-ceramics as artificial bone have active functions in contrast with conventional glasses.

The definition of new glasses comes from the basic concept that they are quite a new material and not the extension of glass. Many kinds of materials are incor-

Table 3 Classification of New Glasses and their Application Fields

\begin{tabular}{|c|c|c|c|}
\hline Function & Glass & Composition & Application \\
\hline \multirow[t]{5}{*}{ Optical } & Optical fiber & $\mathrm{SiO}_{2}$ & $\begin{array}{l}\text { Optical communica } \\
\text { tion micro-optics }\end{array}$ \\
\hline & Glass laser & Phosphate & Fusion \\
\hline & $\begin{array}{l}\text { Photochromic } \\
\text { glass }\end{array}$ & $\begin{array}{c}\mathrm{Na}_{2} \mathrm{O}-\mathrm{Al}_{2} \mathrm{O}_{3}- \\
\mathrm{B}_{2} \mathrm{O}_{3}-\mathrm{SiO}_{2} \\
(\mathrm{Ag}, \mathrm{Cl}, \mathrm{Br})\end{array}$ & Display \\
\hline & Amorphous oxide & Te-O & Laser disc \\
\hline & $\begin{array}{l}\text { Glass for } \\
\text { photomask }\end{array}$ & $\mathrm{SiO}_{2}$, Silicate & Photomask \\
\hline \multirow[t]{2}{*}{ Electronic } & $\begin{array}{l}\text { Super ionic } \\
\text {-conducting glass }\end{array}$ & $\mathrm{AgI}-\mathrm{Ag}_{2} \mathrm{O}-\mathrm{P}_{2} \mathrm{O}_{5}$ & Solid cell \\
\hline & Delay line glass & $\begin{array}{l}\mathrm{R}_{2} \mathrm{O}-\mathrm{PbO}-\mathrm{SiO}_{2} \\
\quad(\mathrm{R}: \text { alkali metal) }\end{array}$ & $\begin{array}{l}\text { TV, video } \\
\text { apparatus }\end{array}$ \\
\hline \multirow[t]{2}{*}{ Thermal } & $\begin{array}{l}\text { Low expansion } \\
\text { glass }\end{array}$ & $\mathrm{TiO}_{2}-\mathrm{SiO}_{2}$ & Microscope \\
\hline & $\begin{array}{l}\text { Low expansion } \\
\text { crystal glass }\end{array}$ & $\begin{array}{l}\mathrm{Li} \mathrm{L}_{2} \mathrm{O}-\mathrm{Al}_{2} \mathrm{O}_{3}-\mathrm{SiO}_{2} \\
\quad\left(\mathrm{ZrO}_{2}-\mathrm{TiO}_{2}\right)\end{array}$ & Heat exchanger \\
\hline \multirow[t]{2}{*}{ Chemical } & Porous glass & $\mathrm{SiO}_{2}$ & $\begin{array}{l}\text { Bioreactor, } \\
\text { catalysis }\end{array}$ \\
\hline & Boro-silicate glass & $\mathrm{B}_{2} \mathrm{O}_{3}-\mathrm{SiO}_{2}$ & $\begin{array}{l}\text { Solidification of } \\
\text { radio wave waste }\end{array}$ \\
\hline Biomedical & $\begin{array}{l}\text { Apatite crystalline } \\
\text { glass }\end{array}$ & $\begin{array}{r}\mathrm{K}_{2} \mathrm{O}-\mathrm{Na}_{2} \mathrm{O}-\mathrm{MgO}- \\
\mathrm{CaO}-\mathrm{P}_{2} \mathrm{O}_{5}-\mathrm{SiO}_{2}\end{array}$ & Tooth crown bone \\
\hline
\end{tabular}

porated into new glasses as shown in Table 3.

\subsection{Semiconducting device materials}

\subsubsection{Visible lasers}

The $0.6 \mu \mathrm{m}$ wavelength range InGaAlP visible laser diodes are attractive light sources for high performance optical information processing systems. After the first room temperature CW operation of InGaAlP laser considerable work has been done on achieving transversemode stabilization, high-power operations, short-wavelength operations and reliability tests.

Since the highest band-gap energy for the claddinglayer material is limited, and a relatively small band-gap energy difference between the active and cladding layers is expected for the InGaAlP system, it is indispensable to well understand the temperature dependence of the threthold current for designing low-threshold current and high-temperature CW operation of InGaAlP lasers, especially in a short-wavelength range.

Here, the temperature dependence of the threshold current for the InGaP-InGaAlP double-heterostructure lasers, whose oscillation wavelength is about $670 \mathrm{~nm}$, has been reported.

\subsubsection{CCD imager}

Due to the expansion of markets in VTR with camera, solid state imager has big markets because of small-size, resistant-vibration, long-term stability, low-energy consumption and no adjustment. The major products of solid state imager for movie are 1/2 inch size. High density picture elements and high sensitivities as well as multifunctions are required for this CCD imager.

$\mathrm{CCD}$ imager has the following major advantages (1) low-cost, (2) low-energy consumption and (3) light weight. Here, next generation CCD imager $\left(4.3 \times 3.6 \mathrm{~mm}^{2}\right)$ has been discussed.

\section{Conclusion}

This is only a summary of the Report submitted by the Committee so that the detail shall be preferably referred to the original reports. It can be said that this survey is not completely sufficient. The uncovered subjects will be supplemented in the following two reports; (1) "The Research and Survey of Ceramics for Lighting" and (2) "The Research and Survey of New Materials for Lighting $^{\prime \prime 2}$.

\section{References}

(1) N. Ichinose: J. Light \& Vis. Env. Vol. 13 No. 2 (1989) 86

(2) N. Ichinose: J. Illum. Engng. Inst. Jpn. Vol. 76 No. 10 (1992) 571 